DOI 10.15393/j9.art.2014.735

\author{
Александр Михайлович Пашков \\ доктор исторических наук, профессор, \\ заведующий кафедрой истории дореволюиионной России, \\ Петрозаводский государственный университет \\ (Петрозаводск, Российская Федераиия) \\ pashkov@psu.karelia.ru
}

\title{
«ЖИТИЕ ЛАЗАРЯ МУРОМСКОГО» КАК СЮЖЕТНЫЙ ИСТОЧНИК ПОЭМЫ Ф. Н. ГЛИНКИ «КАРЕ ЛИЯ **
}

Аннотация. В статье доказывается, что одним из источников поэмы Ф.Н. Глинки «Карелия» было житие Лазаря Муромского - греческого монаха, основавшего в середине XIV века на юго-восточном побережье Онежского озера Успенский Муромский монастырь. Факт этого заимствования не отмечен ни в одном литературоведческом исследовании, посвящённом творчеству Ф.Н. Глинки. Считается, что «Житие Лазаря Муромского» возникло на рубеже XIV-XV веков. В конце XVIII века один из списков «Жития» хранился у крупного петрозаводского чиновника И.А. Пыхтина. В 1805 году И.А. Пыхтин передал свой список «Жития Лазаря Муромского» известному петрозаводскому краеведу Т. В. Баландину, который сделал с него копию. Вскоре Т. В. Баландин передал список со своего «Жития" Лазаря известному историку церкви Евгению (Болховитинову). В 1813 году Евгений опубликовал этот список «Жития Лазаря Муромского» в пятом томе «Истории российской иерархии». В 1826-1830 годах в Петрозаводске отбывал ссылку за участие в движении декабристов поэт Ф.Н. Глинка. Познакомившись с Т.В. Баландиным, он получил от краеведа текст «Жития Лазаря Муромского» и включил в свою поэму «Карелия» рассказ о монахе, переселившемся из Греции в Россию. Кроме того, имя святого упоминается в тексте поэмы и дважды в авторских примечаниях к ней. Тонко чувствуя язык, Ф.Н. Глинка подметил взаимосвязь стиля и достоверности «Жития» Лазаря. Таким образом, «Житие Лазаря Муромского» стало одним из источников, вдохновивших Ф.Н. Глинку на создание поэмы «Карелия», и отчасти определило ее содержание.

Ключевые слова: «Житие Лазаря Муромского», Ф.Н. Глинка, Т.В. Баландин, поэма «Карелия»

B 1830 году вышла в свет поэма Ф.Н. Глинки «Карелия»'. Литературовед В. Г. Базанов, посвятивший не одну свою работу анализу этой поэмы, выделил в ней несколько сюжетных линий и подробно ее проанализировал $[1,6-100 ; 2,113-$ $123 ; 3,33-97]$. Но в условиях того времени, когда эти работы писались, он не мог или не захотел выделить использование 
в поэме сюжетов из «Жития Лазаря Муромского» - греческого монаха, основавшего в середине XIV века древнейшую православную обитель на берегах Онежского озера Успенский Муромский монастырь ${ }^{2}$.

В поэме «Карелия» есть несколько эпизодов, навеянных знакомством Ф.Н. Глинки с «Житием» Лазаря. В первой части поэмы помещен рассказ о живущем на берегах Онежского озера монахе, уроженце Греции («он родом грек») [4, 350]. К этому поэтическому рассказу Ф.Н. Глинка дал примечание: «Рассказ об отшельнике, его переселении с востока на север не есть просто вымысел...» $[4,350]$ В третьей части поэмы помещены вставные новеллы - сказки о богатыре Заонеге. В первой сказке упоминается о посещении Заонегой Муромского монастыря («а Мурму шел он в монастырь») [4, 376]. Четвертая сказка о поединке Заонеги с духами заканчивается так:

Но Лазарь в Мурме зазвонил

(Угодник с братьей там жил)

И духи тотчас присмирели;

И Заонега стал смирен;

Прогнал врагов вечерний звон;

То в Мурме павечерье пели...[4, 381]

К этому отрывку Ф.Н. Глинка дает следующее примечание:

Из имеющегося здесь рукописного жития Лазаря Мурмского, инока, прославившегося святою жизнью в странах, составляющих ныне Олонецкую губернию, видно, что сей Лазарь, уроженец из Рима, жил долгое время в Новгороде и, наконец, по сказанному в бывшем ему видении, отправился к озеру Онеге в Мурмское урочище, которое и поступило впоследствии во владение основанного им монастыря... Лазарь написал сам свое житие слогом простодушным, ручающимся за истину повествования... Житие Лазаря Мурмского в рукописи получил я от Т. В. Баландина, занимающегося здесь в давнего времени описание достопамятностей Олонецкого края» $[4,403]$.

Таким образом, одним из героев поэмы «Карелия» стал Лазарь Муромский, а его «Житие» легло в основу одной из ее 
сюжетных линий. Этот факт не отмечен ни в одном литературоведческом исследовании, посвященном поэме Ф.Н. Глинки.

«Житие Лазаря Муромского» имеет большое значение для истории культуры Карелии. Это первое произведение, написанное на в Карелии и посвященное событиям, происходившим на ее территории. "Житие» посвящено описанию жизни греческого монаха Лазаря и истории основания им в середине XIV века Успенского Муромского монастыря на юго-восточном побережье Онежского озера.

По данным современных исследователей, «Житие Лазаря Муромского» было написано в конце XIV начале XV века ${ }^{3}$. В средневековой Руси жития святых писались по особым канонам и часто до наших дней доходила не первоначальная, наиболее достоверная редакция жития, а так называемая «украшенная» редакция, в которой в ущерб достоверности главное внимание уделялось каноническому набору чудес и добродетелей святого. В отличие от многих «украшенных» агиографических памятников, «Житие» Лазаря дошло до нас в двух редакциях, близких к начальному тексту.

Оригинал «Жития» Лазаря хранился, вероятно, в архиве Муромского монастыря и погиб в конце 1612 начале 1613 года, когда монастырь был разграблен и сожжен отрядами «панов». Однако уже тогда с него были сняты копии, которые хранились у окрестных священников и благочестивых мирян. Эти списки продолжали бытовать в среде крестьян и духовенства Обонежья на протяжении XVI-XVIII веков, пока в конце XVIII века ими не заинтересовались местные собиратели и краеведы. К тому времени Муромский монастырь, восстановленный после Смуты, захирел. При Екатерине II он был подчинен Александро-Свирскому монастырю. Летом 1785 года академик Н.Я. Озерецковский, путешествовавший по Онежскому озеру, нашел там только двух престарелых монахов $[16,185]$. В 1786 году монастырь был обращен в женский, а вскоре и вовсе упразднен и превращен в церковь $[8,129-130 ; 12,11-14]$.

Первым достоверно известным владельцем рукописи «Жития Лазаря Муромского» был Иван Афанасьевич Пыхтин (1734-1806). Это был крупный местный чиновник, от- 
ставной флота капитан-лейтенант, в 1773-1777 годах воеводский товарищ в Олонце, а затем председатель первого департамента верхней палаты Олонецкого областного суда 4 . После переноса административного центра из Олонца в Петрозаводск в 1781 году И.А. Пыхтин тоже переселяется туда. В 1785 году он имел чин надворного советника (по «Табели о рангах» равный подполковнику) и, принадлежа к числу 16 наиболее высокопоставленных петрозаводских чиновников, владел домом («светлицей») с 4 «покоями». Для сравнения, живший тогда в Петрозаводске действительный статский советник, правитель дел Олонецкого наместничества и известный поэт Г. Р. Державин имел дом с 12 «покоями» [15].

В 1805 году И. А. Пыхтин передал свой список «Жития Лазаря Муромского» Тихону Васильевичу Баландину. Т. В. Баландин родился в Петрозаводске в июне 1745 года, вероятно, в купеческой семье ${ }^{5}$. Его дед был «один из первых петрозаводских поселенцев и поставщиком к императорскому двору дичи и других съестных припасов» [7]. Т.В. Баландин известен как выдающийся краевед, писатель, историк и педагог конца XVIII - первой четверти XIX вв. Он был глубоко верующим человеком. Значительную часть своей жизни, с 1779 по 1804 годы, он посвятил паломничеству по православным монастырям России и посетил все крупнейшие обители вокруг С.-Петербурга, Новгорода, Киева, Москвы, Рязани (там он жил в 1785-1794 годах) и Вологды. Т. В. Баландин неоднократно бывал в Соловецком, Палеостровском и Александро-Свирском монастырях. Впервые он посетил эти обители весной 1780 года. В 1794-1795 годах он находился по обету на Соловках, летом 1795 года посетил Александро-Свирский монастырь, а в 1798-1799 годах находился в Палеостровском монастыре. Третья его поездка в Соловки и на Палеостров состоялась в 1802 году, причем в Палеострове он прожил целый месяц. Последнее паломничество в эти две обители «водоплаванием» состоялось летом 1804 года, причем в Палеострове он снова задержался на месяц. Все эти странствования были им подробно описаны в сочинении «Сокращенное повествование о путепродолжениях Tichona Wasilieva (Balandina) 
доселе восприятое и совершенное, по благоговеющей и искренней любви в разные монастыри и о прочем, записанные к собственной памяти и душевному удовольствию»7.

В этот период Т. В. Баландин познакомился со многими образованными православными иерархами, включая митрополитов петербургских Гавриила и Амвросия ${ }^{8}$, архиепископов рязанского Симона и псковского Иринея ${ }^{9}$, архимандритов Соловецкого монастыря Герасима, Новоиерусалимского Иеронима $^{10}$ (его он называет «ученейшим мужем») и многими другими. Т. В. Баландин часто и подолгу беседовал с ними и с некоторыми долгое время переписывался.

В 1803-1804 годах Баландин познакомился с известным историком и библиофилом Евгением (Болховитиновым), с января 1804 года викарным епископом старорусским [9, 207-209], который, во время пребывания Тихона в С.-Петербурге, приглашал его к себе «для угощения» и бесед, давал советы «к постижению иноческой жизни», а после его отъезда в Петрозаводск «удостоил одарением книг и перепискою». Сохранились три письма Евгения к Т.В. Баландину: от 18 февраля 1804 года из Новгорода в С.-Петербург с извещением об отправке адресату трех своих книг, от 9 апреля 1804 года из Новгорода, вероятно, в Петрозаводск с извещением об отправке еще трех «рассуждений» Евгения и от 16 января 1805 года из С.-Петербурга, вероятно, в Петрозаводск (на последнем письме имеется важная для дальнейших изысканий помета «получено 16 февраля 1805 года») ${ }^{11}$. Существовало и несколько писем Т. В. Баландина Евгению, но только одно из них, содержащее поздравление с Новым 1805 годом, сохранилось в бумагах Баландина ${ }^{12}$.

Вероятно, по просьбе своего ученого адресата Т. В. Баландин снимает для него копию «Жития Лазаря Муромского» с протографа, хранившегося у И. А. Пыхтина. В конце текста он сделал приписку:

Списано с полученного списка от его высокоблагородия господина Ивана Афанасьевича Пыхтина по усердию Тихоном Васильевым, жителем Петрозаводским 1805 года февраля 17 дня в Петрозаводске. 
Встретившиеся в списке означенного жития многие по старонаречению от перепищиков неисправности, остались и в сем списке в таком же виде. Для того, чтоб поправкою подлинника далее не погрешить, а затем и представляется оное исправить тем, кто к сему будет предопределен ${ }^{13}$.

Эта авторская приписка показывает, что баландинский список «Жития Лазаря Муромского» был создан в период оживленной переписки между Т.В. Баландиным и епископом Евгением, и текст жития передан, возможно, по рекомендациям последнего, с учетом требований археографии и для последующей научной публикации.

Вероятно, тогда же одна из копий жития была доставлена Евгению, а другая осталась в бумагах Т. В. Баландина, хранящихся ныне в фонде Е.В. Барсова в Отделе письменных источников Государственного исторического музея ${ }^{14}$. Через пятнадцать лет, в 1821-1825 годах, Т.В. Баландин переписал все свои произведения «своеручно» в большой том. Там же оказался и новый список «Жития» Лазаря с припиской «Се писано с полученного старонареченного списка и букв того времени и полученного от друга моего, его высокоблагородия флота капитан-лейтенанта, кавалера и бывшего олонецкого воеводского товарища Ивана Афанасьевича Пыхтина Тихоном Васильевым в Петрозаводске anno 1805». В настоящее время этот список хранится в библиотеке Академии наук ${ }^{15}$.

Судьба протографа, принадлежавшего И.А. Пыхтину, неизвестна. Сам владелец умер 10 мая 1806 года [14, 65], а вскоpe, 12 июня 1811 года, скончалась и его вдова Анна Карловна Пыхтина $[14,22]$. Сам Т. В. Баландин умер в Петрозаводске 26 июня 1830 года $[14,12]$.

Итак, епископ Евгений получил от Т. В. Баландина список «Жития Лазаря Муромского» в феврале-марте 1805 года. Именно в это время он готовится к созданию многотомного труда по истории русской православной церкви «История российской иерархии», опубликованного в семи томах в 1807-1815 годах. Историки церкви и биографы Евгения (Болховитинова) отмечали, что, хотя автором этого труда и был назван Амвросий (Орнатский), именно Евгению «принадлежит половина труда и даже более, если не забывать 
цену инициативы и общей редакции» $[11,19-20 ; 5,60-61]$. В пятом томе «Истории российской иерархии», вышедшем в 1813 году, в статье, посвященной Муромскому Успенскому монастырю, «Житие Лазаря Муромского» было опубликовано с комментариями, можно предположить, самого Евгения (Болховитинова) [8, 115-119]. Эта публикация имела огромное значение, поскольку текст жития стал доступен исследователям. Большинство ученых, изучавших деятельность Лазаря Муромского и его «Житие» в XIX-XX веках, опирались именно на эту публикацию. Таким образом, после 1813 года «Житие Лазаря Муромского» стало широко известно.

В 1826-1830 годах в Петрозаводске отбывал ссылку за участие в движении декабристов Федор Николаевич Глинка ${ }^{16}$. Он был человеком глубоко верующим, склонным к мистицизму (с 1822 года даже стал постоянно записывать в дневнике свои сновидения). Ознакомившись через Т.В. Баландина с «Житием Лазаря Муромского», Глинка включил в свою поэму о Карелии заимствованные оттуда образы и сюжеты. Таким образом, написанное на рубеже XIV-XV веков «Житие Лазаря Муромского» стало одним из источников, вдохновивших ссыльного поэта-декабриста на создание поэмы «Карелия», и отчасти определило ее содержание.

\section{Примечания}

* Работа выполнена при поддержке Российского гуманитарного научного фонда, проект № 14-14-10004 «Литературное наследие петрозаводского краеведа и просветителя XVIII первой трети XIX в. Т. В. Баландина».

1 Все цитаты из поэмы Ф.Н. Глинки «Карелия» даются по изданию: [4, 343-404].

2 Новейшую научную публикацию текста «Жития Лазаря Муромского» см.: $[6,14-19]$.

3 Сводку современных данных о «Житии Лазаря Муромского» см.: [13, 288-290].

4 Биографические данные об И.А. Пыхтине см.: Олонец, управляемый доселе знаменитыми воеводством нижеследующими вельможами // Библиотека Российской Академии наук. Отдел рукописей. Текущие поступления. № 610. Л. 38-39 (далее БРАН ОР). 
5 Год рождения Т. В. Баландина уточнен по данным его формулярных списков за 1813 и 1815 годы (Национальный архив Республики Карелия. Ф. 37. Оп. 5. Д. 86/640. Л. 24об.-25; Д. 74/498. Л.37об.-38) (далее НАРК). В Петрозаводске во второй половине XVIII века существовал купеческий род Баландиных (НАРК. Ф. 63. Оп. 3. Д. 28/238. Л. 291; Д. 34/296. Л. 737об., 741об. и др.).

6 Подробнее о Т.В. Баландине и его деятельности см.: [17, 16-29; 18, $122-130 ; 19,88-110]$.

7 Сокращенное повествование о путепродолжениях Tichona Wasilieva (Balandina) доселе восприятое и совершенное, по благоговеющей и искренней любви в разные монастыри и о прочем, записанные к собственной памяти и душевному удовольствию // Государственный исторический музей. Отдел письменных источников. Ф. 450. Оп. 1. Д. 681. Л. 88-99об. (далее ГИМ ОПИ).

8 Гавриил (Петров) (1730-1801) с 1783 года митрополит С.-Петербургский, с 1786 года - С.-Петербургский и Новгородский, с 1799 года Новгородский и Олонецкий, в декабре 1800 года уволен на покой; Амвросий (Подобедов) (1742-1818) митрополит Новгородский и С.-Петербургский с 1801 года, проповедник.

9 Симон (Лагов) (умер в 1804 году) с 1778 года епископ, с 1792 года архиепископ Рязанский, один из ученейших архиреев русской церкви второй половины XVIII века; Ириней (Клементьевский) (1751-1818) духовный писатель и проповедник, с 1796 года архиепископ Псковский.

10 Герасим (Ионин) архимандрит Соловецкого монастыря с марта 1793 по апрель 1796 года; Иероним (Поняцкий) архимандрит Новоиерусалимского монастыря с января 1799 по июнь 1802 года.

11 Письма Евгения (Болховитинова) Т. В. Баландину от 18.02.1804, 9.04.1804 и 16.01.1805 // ГИМ ОПИ. Ф. 450. Оп. 1. Д. 681. Л. 136-138. Письма Т.В. Баландина Евгению (Болховитинову) (февраль 1805 г.) // ГИМ ОПИ. Ф. 450. Оп. 1. Д. 681. Л. 138 об.

Житие преподобного Лазаря Муромского Чудотворца // ГИМ ОПИ. Ф. 450. Оп. 1. Д. 681. Л. 173об.

Житие преподобного Лазаря Муромского Чудотворца // ГИМ ОПИ. Ф. 450. Оп. 1. Д. 681. Л. 165-173об.

Житие преподобного Лазаря Муромского Чудотворца // БРАН ОР. Текущие поступления. № 610. Л. 51-57об. 
А. М. Пашков

\section{Список литературы}

1. Базанов В.Г. Карельские поэмы Федора Глинки. Петрозаводск: Гос. изд-во Карело-Финской ССР, 1945. 128 с.

2. Базанов В.Г. Поэтическое наследие Федора Глинки (10-30 годы XIX века). Петрозаводск: Гос. изд-во Карело-Финской ССР, 1950. 128 с.

3. Базанов В.Г. Карелия в русской литературе и фольклористике XIX века. Очерки. Петрозаводск: Госиздат Карело-Финской ССР, 1955. $311 \mathrm{c}$.

4. Глинка Ф.Н. Избранные произведения. Л.: Советский писатель, Ленинградское отделение, 1957. $501 \mathrm{c}$.

5. Жерве Н.Н. Труды митрополита Евгения (Болховитинова) по истории русской церкви // Вспомогательные исторические дисциплины: высшая школа, исследовательская деятельность, общественные организации. М.: РГГУ, 1994. С. 60-61.

6. Житие Лазаря Муромского / Пер. и примеч. А. В. Пигина // Кижский вестник: Сб. ст. Вып. 8. Петрозаводск: Государственный историко-архитектурный и этнографический музей-заповедник «Кижи», 2003. С. $14-19$.

7. Журнал губернского статистического комитета // Олонецкие губернские ведомости. 1866. № 6.

8. Завещание преподобного Лазаря Муромского Чудотворца // Амвросий (Орнатский). История российской иерархии. М.: Синодальная типография, 1813. Т. 5. С. 114-130.

9. Зорин А. П. Евгений // Русские писатели. 1800-1917 гг. Биографический словарь. М.: Большая российская энциклопедия, 1992. Т. 2. С. 207-209.

10. Ильин-Томич А.А. Глинка Федор Николаевич // Русские писатели. 1800-1917 гг. Биографический словарь. М.: Большая российская энциклопедия, 1992. Т. 1. С. 578-581.

11. Карташев А.В. Очерки по истории русской церкви. М.: Изд. центр «Терра», 1993. T. 1.686 с. (первое издание: Париж: YMCA-PRESS, 1959).

12. Костин А.Г. Православная Пудога. Петрозаводск: Ин-т повышения квалификации педагогических кадров, 1994. 48 с.

13. Литвинова Н. К., Прохоров Г. М. Житие Лазаря Муромского // Словарь книжников и книжности Древней Руси. Вып. 2 (вторая половина XIV - XVI в.). Ч. 1. А - К. Л.: Наука, 1988. С. 288-290.

14. Мошина Т. А. Петрозаводский некрополь. Справочник. Петрозаводск: Изд-во КарНЦ РАН. 2009. 92 с.

15. Народонаселение Петрозаводска в 1785 году // Олонецкие губернские ведомости. 1864. № 11. С. 48-49. 
16. Озерециковский Н.Я. Путешествие по озерам Ладожскому и Онежскому. Петрозаводск: Карелия, 1989. 208 с. (первое издание: СПб., 1792).

17. Пашков А. М. Т.В. Баландин - малоизвестный петрозаводский просветитель конца XVIII - начала XIX вв. // Вопросы истории Европейского Севера: Межвуз. сб. науч. ст. Петрозаводск, 1991. С. 1629.

18. Пашков А. М. «В стране знатнейших северных холмов...» (Т. В. Баландин первый историк Петрозаводска) // Север. 1997. № 7. С. 122130.

19. Пашков А.М. Карелия и Соловки глазами литераторов пушкинской эпохи. Петрозаводск: Изд-во ПетрГУ, 2000. 176 с.

20. Пашков А.М. Петрозаводская ссылка Ф.Н. Глинки // Памятники Отечества. 1989. № 1(19). С. 56-60.

\title{
Alexandr Mikhailovich Pashkov
}

\author{
Doctor of History, Professor \\ of Petrozavodsk State University \\ (Petrozavodsk, Russian Federation) \\ pashkov@psu.karelia.ru
}

\section{THE VITA OF LAZAR OF MUROM AS A HISTORICAL SOURCE OF FYODOR GLINKA'S POEM KARELIA}

Absrtact. The article proves that one of the sources of Fyodor Glinka's poem Karelia was the legend describing The Vita of Lazar of Murom - a Greek monk who founded the Murom Monastery of St. Assumption on the southeastern shore of Onega Lake in the middle of the 14th century. This fact has not been mentioned yet in any of the literature studies devoted to Glinka's works. It is believed that The Vita of Lazar of Murom was created during the period between the late 14th and early 15th century. At the end of the 18th century this manuscript's copy belonged to a high rank Petrozavodsk official I. A. Pykhtin. In 1805, he consigned his copy of The Vita of Lazar of Murom to a well-known Petrozavodsk historian T. V. Balandin, who made another copy of it. Soon T.V. Balandin transferred his copy to a famous Orthodox church historian Evgenii (Bolkhovotinov), who in turn published this copy in 1813 in the 5th volume of his work The History of Russian Hierarchy. In 1826-1830, poet Fyodor Glinka was sent to exile in Petrozavodsk for having participated in the Decembrist movement. He met T. V. Balandin, read the text of The Vita of Lazar of Murom and included a story about a monk who had moved from Greece to Russia into his poem Karelia, published in 1830. Besides, the name of Saint Lazar is mentioned in the main text of the poem and twice in its footnotes. Glinka had a great intuitive feel for a language and noticed correlation between style and authenticity of the legend about Lazar's life. So, 
А. М. Пашков

The Vita of Lazar of Murom became one of the sources which inspired Fyodor Glinka to create his poem Karelia and to certain extent determined its content.

Keywords: The Vita of Lazar of Murom, Fyodor Glinka, T. V. Balandin, poem Kaleria

\section{References}

1. Bazanov V.G. Karel'skie poemy Fedora Glinki [Karelian poems of Feodor Glinka]. Petrozavodsk, Karelo-Finnish SSR Publ., 1945. 128 p.

2. Bazanov V. G. Poeticheskoe nasledie Fedora Glinki (10-30 gody XIX veka) [Poetical Heritage of Feodor Glinka (10-30s of the 19th century)]. Petrozavodsk, Karelo-Finnish SSR Publ., 1950. 128 p.

3. Bazanov V.G. Kareliya $v$ Russkoy Literature $i$ Fol'kloristike XIX veka. Ocherki [Karelia in Russian Literature and Folklore Studies of the 19th century. Essays]. Petrozavodsk, Karelo-Finnish SSR Publ., 1955. 311 p.

4. Glinka F. N. Izbrannye proizvedeniya [Selected works]. Leningrad, Sovetskiy pisatel' Publ., Leningradskoe otdelenie, 1957. 501 p.

5. Zherve N.N. Trudy mitropolita Evgeniya (Bolkhovitinova) po istorii russkoy tserkvi [Works of Metropolitan Eugenii (Bolkhovitinov) on the History of the Russian Church]. Vspomogatel'nye istoricheskie distsipliny: vysshaya shkola, issledovatel'skaya deyatel'nost', obshchestvennye organizatsii [Auxiliary historical disciplines: high school, scholar activity, civil society organizations]. Moscow, Russian State University for the Humanities Publ., 1994, pp. 60-61.

6. Zhitie Lazarya Muromskogo [The Holy Life of Lazar from Murom]. Kizhskiy vestnik (sbornik statey) [Kizhi Herald (collection of articles)]. Part 8. Petrozavodsk, Kizhi state open-air museum of history, architecture and ethnography, 2003, pp. 14-19.

7. Zhurnal gubernskogo statisticheskogo komiteta [Journal of provincial statistic committee]. Olonetskie gubernskie vedomosti [Olonets provincial gazette]. 1866. no. 6.

8. Zaveshchanie prepodobnogo Lazarya Muromskogo Chudotvortsa [The Testament of the Reverend wonder-worker Lazar from Murom]. Amvrosiy (Ornatskiy). Istoriya Rossiyskoy ierarkhii [Amvrosiy (Ornatskiy). The History of Russian hierarchy]. Moscow, Synod Printing House, 1813, vol. 5, pp. 114-130.

9. Zorin A.P. Eugeniy [Eugeniy]. Russkie pisateli. 1800-1917 gg. Biograficheskiy slovar' [Russian writers. 1800-1917s. Biographical dictionary]. Moscow, Bol'shaya rossiyskaya entsiklopediya Publ., 1992, vol. 2, pp. 207-209.

10. Il'in-Tomich A. A. Glinka Fedor Nikolaevich [Glinka Fedor Nikolaevich]. Russkie pisateli. 1800-1917 gg. Biograficheskiy slovar' [Russian writers. 1800-1917s. Biographical dictionary]. Moscow, Bol'shaya rossiyskaya entsiklopediya Publ., 1992, vol. 1, pp. 578-581. 
11. Kartashev A.V. Ocherki po istorii russkoy tserkvi [Studies on the History of the Russian Church]. Moscow, Izdatel'skiy tsentr «Terra», 1993, vol. 1. 686 p. (the 1st edition: Paris, YMCA-PRESS, 1959).

12. Kostin A. G. Pravoslavnaya Pudoga [Orthodox Pudoga]. Petrozavodsk, Institut povysheniya kvalifikatsii pedagogicheskikh kadrov Publ., 1994. $48 \mathrm{p}$.

13. Litvinova N.K., Prokhorov G. M. Zhitie Lazarya Muromskogo [The Holy Life of Lazar from Murom]. Slovar' knizhnikov i knizhnosti Drevney Rusi [The dictionary of Ancient Russia scribes and booklore]. Vol. 2 (2nd half of 14th - 16th centuries). Part 1. A-K. Leningrad, Nauka Publ., 1988, pp. 288-290.

14. Moshina T.A. Petrozavodskiy nekropol'. Spravochnik [Petrozavodsk necropolis. Guide]. Petrozavodsk, Karelian Research Centre RAS Publ., 2009. $92 \mathrm{p}$.

15. Narodonaselenie Petrozavodska v 1785 godu [Population of Petrozavodsk in 1785]. Olonetskie gubernskie vedomosti [Olonets provincial gazette]. 1864, no. 11, pp. 48-49.

16. Ozeretskovskiy N. Ya. Puteshestvie po ozeram Ladozhskomu i Onezhskomu [The journey over Ladoga and Onega Lakes]. Petrozavodsk, Karelia Publ., 1989. 208 p. (the 1st edition: Saint-Petersburg, 1792).

17. Pashkov A. M. T. V. Balandin - maloizvestnyy petrozavodskiy prosvetitel' kontsa XVIII - nachala XIX vekov [T. V. Balandin - a little-known Petrozavodsk enlightener of the late 18th - early 19th centuries]. Voprosy istorii Evropeyskogo Severa [Problems of European North History]. Petrozavodsk, Petrozavodsk State University Publ., 1991, pp. 16-29.

18. Pashkov A. M. "V strane znatneyshikh severnykh kholmov..." T. V. Balandinpervyy istorik Petrozavodska ["In the country of splendid Northern hills..." T. V. Balandin is the first historian of Petrozavodsk]. Sever [The North], 1997. no. 7, pp. 122-130.

19. Pashkov A.M. Kareliya i Solovki glazami literatorov pushkinskoy epokhi [Karelia and Solovetsky monastery from the viewpoint of literary men of Pushkin's times]. Petrozavodsk, Petrozavodsk State University Publ., 2000. $176 \mathrm{p}$.

20. Pashkov A.M. Petrozavodskaya ssylka F. N. Glinki [Petrozavodsk exile of F. N. Glinka]. Pamyatniki Otechestva [Monuments of Motherland]. 1989, no. 1 (19), pp. 56-60. 